\title{
Observations on the Effect of Feeding Labeo rohita (Ham.) with Microcystis aeruginosa Kütz
}

\author{
by \\ Mirza Rashid Ahmad \\ Department of Botany, Christ Church College, Kanpur (India)
}

\section{INTRODUCTION}

The importance of algae which form major fish food has been realized in fish farming during the current years. Recently, a number of attempts have been made to study the feeding habits of freshwater fishes. Among algae, the blue greens form a better source of food for the fishes than other plants (SINGH, R. N., 1961). There is diversity of opinion regarding the toxicity of Microcystis aeruginosa on freshwater fishes. The toxic effect of $M$. aeruginosa on freshwater fishes has been reviewed by PrescotT (1948), INGRAM \& PresCott (1954) and SCHELUBSKY (1951) etc. But the investigations made in India have shown that the alga is not toxic to freshwater fishes (GANAPATI, 1940, 1956, 1960; SINGH, 1958; KRISHNAMOORTHY, 1961 and GEORGE 1962 etc.). The author himself studied a permanent fishery pond at Kanpur for two years containing a number of fishes of commercial importance with a bloom of $M$. aeruginosa causing no mortality of fishes.

The present investigation has been made to study the utility of $M$. aeruginosa as fish food for Labeo rohita, an important Carp of India, while dealing with the problem entitled "Studies on algae with special reference to freshwater fishes of Kanpur".

Received December 24th, 1965. 


\section{MATERIAL AND METHODS}

The fingerlings of Labeo rohita were obtained from the local Government nursery. The fishes were acclimatized to laboratory conditions and controlled feeding experiments were carried out in rectangular jars containing 3 litres of water. The experiment was set in triplicate. The fishes were starved for about 48 hours to clear their gut contents. The experiments were then set up in three jars each containing four fishes. One of the jars contained $M$. aeruginos $a$ and tap water, the other contained Hydrilla sp. with pond water, thus simulating almost natural condition and the third jar contained tap water only. The second and third jars were used as control. $M$. aeruginosa used for the experiments was collected from a permanent pond. The water was well aerated and was not changed during the experiments. The experiments were continued for a week and weight, volume and measurements of fishes were taken before and after the experiments. The weight was taken by transferring the fish to a beaker containing a weighed quantity of water. The beaker was then weighed on a chemical balance. The volume was determined by transferring the fish to a measuring cylinder. The fishes were measured to the nearest millimeters. To determine the condition of alga, excreta was examined daily.

\section{OBSERVATIONS}

The effect of feeding $M$. aeruginosa on the weight, volume and size of Labeo rohita is recorded in Table I.

Table I shows that there is an increase of $31.11 \%$ in weight, $12.5 \%$ increase in volume, $1.923 \%$ increase in length and $5.05 \%$ increase in breadth of fishes in the jar No. 1 fed with $M$. aeruginosa. Fishes in jar No. 2, simulating almost natural conditions also show an increase of $19.189 \%$ in weight, no increase in volume, $0.406 \%$ increase in length and $2.857 \%$ in breadth. This shows that the effect of feeding the fishes with alga is very marked as compared to the fishes kept in jar No. 2. The fishes kept in jar No. 3 were practically starved and lost $20.90 \%$ in weight, $12.5 \%$ in volume and $6.33 \%$ in breadth. However, there was no change in the length of the fishes. No mortality of the fishes encurred during the experiments. The general behaviour of fishes was better in jar No. 1 and 2 as compared to jar No. 3. An examination of the excreta in jar No. 1 showed cells of $M$. aeruginosa in various stages of disintegration.

\section{Discussion}

The results of the present study indicate that feeding with $M$. 
TABLE I

The effect of feeding Labeo rohita with Microcystis aeruginosa.

\begin{tabular}{c|c|c|c|c|c|c|c}
\hline $\begin{array}{c}\text { Type of } \\
\text { water and } \\
\text { inoculum }\end{array}$ & $\begin{array}{c}\text { Initial } \\
\text { weight of } \\
\text { fishes in } \\
\text { g. }\end{array}$ & $\begin{array}{c}\text { Final } \\
\text { weight of } \\
\text { fishes in } \\
\text { g. }\end{array}$ & $\begin{array}{c}\text { Difference } \\
\text { in } \\
\text { weight. }\end{array}$ & $\begin{array}{c}\text { Percentage } \\
\text { increase } \\
\text { or } \\
\text { decrease } \\
\text { in } \\
\text { weight }\end{array}$ & $\begin{array}{c}\text { Initial } \\
\text { volume } \\
\text { in } \\
\text { ml. }\end{array}$ & $\begin{array}{c}\text { Final } \\
\text { volume } \\
\text { in } \\
\text { ml. }\end{array}$ & $\begin{array}{c}\text { Difference } \\
\text { in } \\
\text { Volume }\end{array}$ \\
\hline $\begin{array}{c}\text { Jar No. 1 } \\
\text { Tap water } \\
\text { and }\end{array}$ & 4.5600 & 5.9790 & 1.4190 & $\begin{array}{c}31.11 \\
+\end{array}$ & 4.00 & 4.5 & 0.5 \\
\begin{tabular}{c} 
M. aeruginosa \\
\hline $\begin{array}{c}\text { Jar No. 2 } \\
\text { Pond water } \\
\text { and }\end{array}$
\end{tabular} & 5.1590 & 6.0490 & 0.9900 & $\begin{array}{c}19.189 \\
+\end{array}$ & 4.00 & 4.00 & Nil \\
\begin{tabular}{c} 
Hydrilla sp \\
\hline $\begin{array}{c}\text { Jar No. 3 } \\
\text { Tap water } \\
\text { CONTROL }\end{array}$
\end{tabular} & 4.4690 & 4.3390 & 0.1300 & 20.90 & 4.00 & 3.5 & 0.5 \\
\hline
\end{tabular}

aeruginosa has a beneficial effect on growth and development of fingerlings of Labeo rohita. There is overall improvement in the general condition, increase in weight, volume and size of fishes fed with the alga. The distintegrated cells present in excreta; in different stages show that the alga is being utilized by the fishes as food. The beneficial effect of Microcystis aeruginosa may be ascribed to the high nutritive value as the alga contains $53.12 \%$ crude protein (SINGH, R. N., 1961).

It would be interesting to compare the results of the present observation with the literature available on the role of algae as fish food. The effect of feeding Puntius ticto (HAM.) and Trichogaster fasciatus Day with Scenedesmus obliquus (TURPIN) KUETZING (GUPTA \& AHMAD, 1964 and GuPTA \& AHMAD, 1966) Cirrhina mrigala (HAM.) with Microcystis aeruginosa (AHMAD, 1966) have shown that the algae impart an improved fish growth.

The findings of the present study are in conformity with the previous work and suggest that the feeding of fishes with algae rich in proteins yields significant improvement in general conditions and growth of fishes. 


\begin{tabular}{|c|c|c|c|c|c|c|c|c|}
\hline \multirow{2}{*}{$\begin{array}{c}\text { Percentage } \\
\text { increase } \\
\text { or } \\
\text { decrease } \\
\text { in } \\
\text { volume }\end{array}$} & \multicolumn{2}{|c|}{$\begin{array}{l}\text { Average initial } \\
\text { measurements } \\
\text { in } \mathrm{cm} .\end{array}$} & \multicolumn{2}{|c|}{$\begin{array}{l}\text { Average final } \\
\text { measurements } \\
\text { in } \mathrm{cm} .\end{array}$} & \multicolumn{2}{|c|}{$\begin{array}{l}\text { Difference in } \\
\text { measurements }\end{array}$} & \multicolumn{2}{|c|}{$\begin{array}{c}\text { Percentage } \\
\text { increase or } \\
\text { decrease }\end{array}$} \\
\hline & Length & Breadth & Length & Breadth & Length & Breadth & Length & Breadth \\
\hline $\begin{array}{c}12.5 \\
+\end{array}$ & 5.2 & 0.95 & 5.30 & 1.0 & 0.1 & 0.05 & $\begin{array}{c}1.9230 \\
+\end{array}$ & $\begin{array}{c}5.05 \\
+\end{array}$ \\
\hline Nil & 5.425 & 0.875 & 5.450 & .85 & 0.025 & 0.025 & $\begin{array}{c}0.406 \\
+\end{array}$ & $\begin{array}{c}2.857 \\
+\end{array}$ \\
\hline 12.5 & 5.75 & 0.825 & 5.75 & .775 & Nil & 0.050 & Nil & 6.33 \\
\hline
\end{tabular}

\section{SUMMARY}

Controlled feeding experiments were carried out with Microcystis aeruginosa to study its effect on the fingerlings of Labeo rohita. The observation reveals an overall improvement in the general condition and a marked increase in weight, volume and size of fishes as compared to control.

\section{ACKNOWLEGDEMENTS}

I am highly indebted to Dr. A. B. Gupta for his guidance and supervision during the course of this investigation and to $\mathrm{Mr}$. A. C. SHUKLA for his help. Thanks are also due to the Council of Scientific and Industrial Research, Government of India, New Delhi, for the award of Junior Research Fellowship. 
Armad, M. R. - 1966 - Some observations on the effect of feeding Cirrhina mrigala (Ham.) with Microcystis aeruginosa Kütz. Hydrobiologia, 28, $88-90$.

GaNAPATI, S. V. - 1940 - The ecology of a temple tank containing a permanent bloom of Microcystis aeruginosa Kütz. F. Bom. Nat. Hist. Soc. 42(1). 65-77.

Ganapati, S. V. - 1956 - D. Sc. Thesis, University of Madras.

Ganapati, S. V. - 1960 - Ecology of tropical waters. Proc. Symp. Algology. UNESCO, New Delhi, 204-218.

GeorGE, M. G. - 1962 - Occurrence of a permanent algal bloom in a fish tank at Delhi, with special reference to factors responsible for its production. Proc. Indian Acad. Sci. 56(6) sect. B., 354-362.

Gupta, A. B. \& AHMAD, M. R. - 1964 - Some experimental observations on the use of Scenedesmus obliquus (Turpin) Kuetzing by Puntius ticto (Hamilton) and Trichogaster fasciatus Day. L. F. Sci. Tech. India, 2(3), 203.

GuptA, A. B. \& AHMAD, M.R. - 1966 - Studies on the effect of feeding some fresh water fishes with Scenedesmus obliquus (Turpin) Kuetzing. Hydrobiologia, 28, 42-48.

Ingram, W. M. \& Prescott, G. W. - 1954 - Toxic fresh water algae. Amer. Midl. Naturalist. 52(1) 75-87.

KRISHNAMOORTHI, K. P. - 1961 - A review on some aspects of fish mortality Bull. CPHERI, Nagpur (India )3(4) 1-6.

PrescotT, G. W. - 1948 - Objectionable algae with reference to the killing of fish and other animals. Hydrobiologia 1 (1): 1-13.

SINGH, R. N. - 1961 - Role of blue green algae in Nitrogen economy of Indian agriculture. I.C.A.R. Monograph on algae. New Delhi.

SingH, V. P. - 1958 - Algal food of some local fishes. Indian F. Agric. Sci. Sci. 28(3) 403-408.

SCHELUBSKY, M. - 1951 - Verh. Int. Verein. Limnol. 11: 362-366. 